\title{
UDEJANJANJE NAČEL TRAJNOSTNEGA RAZVOJA V MALIH, ANTROPOGENO PREOBREMENJENIH POREČJIH
}

\author{
Centralna čistilna naprava Šaleške doline, osrednji cilj sanacijskega \\ programa Paka
}

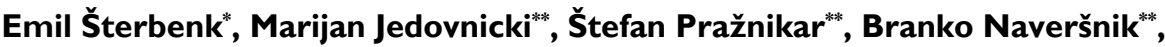 \\ Vesna Metelko-Skutnik**, Alenka Rošer Drev* \\ *ERICo Velenje, inštitut za ekološke raziskave. Koroška 58, 3320 Velenje \\ ** Komunalno podjetje Velenje. Koroška 37/b, 3320 Velenje \\ **ak Agencija Republike Slovenije za okolje, Vojkova I/b, I000 Ljubljana
}

Izvirni znanstveni članek

COBISS 1.01

\section{Izvleček}

Sredi osemdesetih let dvajsetega stoletja so bile vode v Šaleški dolini močno onesnažene. Njihova degradiranost je botrovala nastanku sanacijskega programa. Metodologijo okoljske sanacije porečja Pake je mogoče prilagoditi in uporabiti tudi za druga podobna preobremenjena območja.

Ključne besede: voda, trajnostni razvoj, komunalna čistilna naprava, sanacijski program.

\section{REALIZING OF PRINCIPLES OF SUSTAINABLE DEVELOPMENT IN SMALL OVERBURDENED WATERSHEDS}

Central wastewater treatment plant of the Šalek Valley, main measure of the Water improvement programme Paka

\begin{abstract}
In the mid-eighties of the $20^{\text {th }}$ century waters in the Šalek Valley were heavily polluted. Due to degradation of waters a Water improvement programme was started. Methodology of environmental improvement of Paka watershed could be adjusted and applied also in other similar over-burdened areas.
\end{abstract}

Key words: water, sustainable development, wastewater treatment plant, water improvement programme 


\section{UVOD}

Večji del Slovenije lahko označimo kot povirno območje, za katerega je značilna gosta, a šibka rečna mreža. Paka je tipičen vodotok za povirno območje, saj je dolga slabih $40 \mathrm{~km}$, njeno porečje pa obsega vsega $210 \mathrm{~km}^{2}$ površine. Glavnino porečja, ki leži v predalpskem svetu, predstavlja tektonsko preoblikovano območje srednjega toka, Šaleška dolina (Velenjska kotlina). Dokaj obsežen ravninski predel je že naravno ugoden za poselitev. Zaradi velikih zalog pliocenskega lignita so v Velenju zgradili premogovnik. Ob premogovništvu sta se razvili elektroenergetika in industrija. Obilica delovnih mest je v drugi polovici dvajsetega stoletja Velenje spremenila $v$ enega pomembnejših centrov ekonomske imigracije v takratni Jugoslaviji. Naštete dejavnosti so območje obremenile preko meja samočistilne sposobnosti in zaradi tega je Šaleška dolina postala eno okoljsko najbolj degradiranih območij v Sloveniji. Onesnaženost voda je bila ena najvidnejših posledic intenzivne gospodarske dejavnosti. Vode so se začele slabšati z izgradnjo Termoelektrarne Šoštanj, širjenjem naselij, zlasti Velenja, in zaradi šoštanjske usnjarne, ki je bila najstarejši industrijski objekt. Onesnaževanje je doseglo višek sredi osemdesetih let dvajsetega stoletja. Odgovori na tako slabo stanje so bili načrti za zmanjšanje onesnaževanja vode zaradi premogovništva, elektroenergetike in industrije ter gradnja centralne čistilne naprave za komunalne odpadne vode v spodnjem delu Šaleške doline. Glavni odvodni kanal (kolektor) in mehanska stopnja čistilne naprava sta bila zgrajena že leta 1990 in takrat začela tudi poskusno obratovati. Kanalizacijski sistem je bil takrat še delno nepovezan, zato ni bilo zaznati pomembnejših učinkov čiščenja. Industrijsko, premogovniško in elektroenergetsko onesnaževanje pa je tudi močno presegalo samočistilno sposobnost Pake. Leta 1991 so na takratni Občini Velenje sprejeli usmeritve za ekološki sanacijski program, katerega del je bil tudi sanacijski program »Vode občine Velenje«.

\section{HIDROGEOGRAFSKE POTEZE PAKE}

Srednji pretok Pake v Šoštanju po podatkih Agencije RS za okolje v obdobju 1971/2000 znaša $2,3 \mathrm{~m}^{3} / \mathrm{s}$. Takšne vrednosti pretoka pa so prej izjema kot pravilo, saj so pretoki večji del nižji od srednjega pretoka. Paka je hudournik, zato pretok izrazito koleba. Najmanjša izmerjena vrednost $\mathrm{v}$ istem obdobju je znašala $0,02 \mathrm{~m}^{3} / \mathrm{s}$, največja pa $112 \mathrm{~m}^{3} / \mathrm{s}$. Razmerje med najvišjim in najnižjim absolutnim pretokom je 1:5600. V zadnjem nizu hidroloških meritev (1971/2000) smo Pako uvrstili med vodotoke s pluvio-nivalnim režimom. Zaradi jesenskih padavin ima največ vode novembra, drugi višek v marcu pa je posledica taljenja snega. Spričo snežne retinence so najmanjši pretoki januarja, zaradi presežka izhlapevanja nad padavinami pa je drugi nižek v avgustu. Najbolj kritični so pretočni ekstremi, saj je ob najnižjih pretokih nevarnost, da pretok ne doseže ekološko sprejemljive vrednosti, ob visokih pretokih pa občasno prihaja do poplav. V obdobju 1954/80 je srednji pretok Pake v Šoštanju znašal 2,6 m³ $/ \mathrm{s}$, v naslednjem obdobju (1961/90) $2,5 \mathrm{~m}^{3} / \mathrm{s}$ in v zadnjem (1971/2000) $2,3 \mathrm{~m}^{3} /$ s. Odkar obratujeta centralni kanalizacijski kolektor in čistilna naprava, povprečno $200 \mathrm{l} / \mathrm{s}$ vode teče po cevi ob Paki in se izliva vanjo dobrega pol kilometra, pod merilnim mestom v Šoštanju. 
Zgornje porečje Pake obsega $47 \mathrm{~km}^{2}$, dolžina toka v njem pa $18,8 \mathrm{~km}$ ali skoraj polovico njene dolžine. Dolina v zgornjem porečju je ozka, pobočja strma, povprečni strmec v tem delu pa znaša 46 \%o. Paka ima v tektonsko preoblikovani Šaleški dolini poteze ravninske reke. Njen tok skozi Šaleško dolino je dolg $10 \mathrm{~km}$. Na tem odseku se dolina od Šaleka do Penka spusti za $50 \mathrm{~m}$, torej je njen strmec precej manjši kot v zgornjem toku, in sicer 5\%o. Po nekdaj neposeljeni aluvialni ravnici je Paka meandrirala ter se brez večje škode razlivala. Da so lahko dolino urbanizirali in zgradili Velenje, so morali Pako skozi Šaleško dolino izravnati, strugo pa povečati in utrditi. Prvotno je bila struga Pake skozi Šaleško dolino 2 km daljša, povprečni strmec je na tem predelu zato bil še manjši - 4 \%o. Skrajšanemu toku se ni povečal le strmec, ampak so se poslabšale tudi njegove biotopske in okoljske lastnosti. Srednje porečje je daleč najobsežnejše po površini, saj obsega $140 \mathrm{~km}^{2}$ oziroma dve tretjini celotnega porečja. V Penku se začne spodnje porečje Pake, ki ima še malo manjši strmec kot srednje in predstavlja ozemeljsko najmanjši del, ki meri vsega $25 \mathrm{~km}^{2}$. V $12 \mathrm{~km}$ se površje spusti z nadmorske višine 350 na 305 m, oziroma ima padec slabe $3 \%$.

V Šaleško dolino Paka priteče zelo dobre kakovosti, v dolini koncentrirane proizvodne dejavnosti in naselja Pako dokaj obremenjujejo, v spodnjem toku pa je samočistilna sposobnost Pake zaradi manjšega strmca tudi manjša, tako da je bilo nujno potrebno v spodnjem delu srednjega toka Pake zgraditi čistilno napravo.

Poleg naštetega so hidrogeografske poteze porečja Pake v Šaleški dolini bistveno modificirala ugrezninska jezera, ki so nastala zaradi izkopavanja premoga. Okoli $10 \mathrm{~km}$ dolga in približno 2 km široka Šaleška dolina je že po naravi asimetrična. Večji in bolj vodnati pritoki so Pako potisnili ob njen skrajni južni rob. Jezera so nastala v osrčju Šaleške doline, vendar ne na Paki, temveč na njenih desnih pritokih, ki dolino prečkajo (Šterbenk, Radinja 1997). Za jezera je to z vidika kakovosti dobro, saj je Paka znatno bolj onesnažena kot pritoki, z vidika pretočnosti pa ne, ker so pritoki, ki jezera napajajo, manj vodnati. Pokrajina se je spremenila iz rečne v jezersko, ki je za človekove vplive dosti občutljivejša. Zaradi jezer so v Šaleški dolini nastale zaloge vode, ki presegajo 45 milijonov $\mathrm{m}^{3}$. Največje, Velenjsko jezero, vsebuje po podatkih iz leta 200630 milijonov $\mathrm{m}^{3}$ vode. Zaradi šibkih pritokov Lepene in Sopote teoretična menjava vode traja že skoraj tri leta. Boljša je situacija pri Družmirskem jezeru, ki vsebuje dobrih 15 milijonov $\mathrm{m}^{3}$ vode, ki se teoretično menja približno dvakrat letno.

\section{NAČRTOVANJE, IZGRADNJA IN DELOVANJE CENTRALNE ČISTILNE NAPRAVE ŠALEŠKE DOLINE}

\section{I Zakonodajni vidik pri izgradnji I. faze centralne čistilne naprave}

V času priprave projektno tehnične dokumentacije za I. fazo čistilne naprave je takrat veljavni Zakon o vodah (Ur. list SRS št. 38/81) določal, da so za vsako spremembo vodnega režima, ki lahko nastane s posegi v naravni ali umetni vodotok in vodna zemljišča, s katerimi se spreminja količina, kakovost ali časovna razporeditev voda, potrebna vodnogospodarska soglasja in vodnogospodarska dovoljenja. Določila in zahteve v zvezi s kakovostjo voda pa so 
bila podrobneje določena s predpisom »Strokovno navodilo o tem, katere snovi se štejejo za nevarne in škodljive snovi in o dopustnih temperaturah vode« (Ur. list SRS št. 18/85).

Ker je bilo v sušnih obdobjih pričakovati razmerje med količino iztoka izčistilne naprave in količino vode v reki Paki 1:1, v primeru predpisane dopustne vrednosti $\mathrm{BPK}_{5}$ na izpustu v vodotok (30 mg/l) v sušnih obdobjih ne bi bilo doseženo zadostno izboljšanje kakovosti vode pod iztokom iz čistilne naprave in bi bila Paka tam še vedno v IV. kakovostnem razredu. Dolgoročni cilj pa je dvig kakovosti vode na spodnjem odseku reke Pake v II. kakovostni razred. Ob upoštevanju samočistilne sposobnosti spodnjega odseka bi morala biti Paka pod iztokom čistilne naprave v III. kakovostnem razredu, da bi bil ta cilj dosežen. Republiški komite za varstvo okolja in urejanje prostora je izdal vodnogospodarsko soglasje, v katerem so bile podane zahteve za dimenzioniranje čistilne naprave za popolno biološko čiščenje, vključno z nitrifikacijo in denitrifikacijo $\left(\mathrm{BPK}_{5}<15 \mathrm{mg} / 1\right.$, nitrifikacija $90 \%$, denitrifikacija 80\%). V letu 1990 je bila zgrajena I. faza čistilne naprave, v okviru katere so zgradili mehansko stopnjo čiščenja in aerobno stabilizacijo blata, stopnje za biološko čiščenje pa ne.

\subsection{Kakovost Pake pred sanacijskim programom}

Prvi podatki o izredni kemijski onesnaženosti Pake so bili objavljeni na posvetu Varstvo okolja v energetskih objektih, v Šoštanju, (Dular, Zagorc-Končan, Rejic, Jedovnicki 1984). Prve saprobiološke podatke o kakovosti Pake iz let 1984 in 1985 pa je v svoji diplomski nalogi spremljala Alenka Rošer Drev (1987). Nad Velenjem je bila Paka v I. kakovostnem razredu, v Skornem v III. in v Rečici ob Paki v IV. Celoviti monitoring Pake so zastavili 1987, ko je začela v okviru Rudarsko elektroenergetskega kombinata Velenje delovati ekološka skupina. Prve raziskave in kasnejši monitoring so dokazali, da je Paka močno onesnažena, saj je bil precejšen del toka v Šaleški dolini in pod njo uvrščen v IV. kakovostni razred.

Takratna občina Velenje je na inštitutu ERICo Velenje let 1992 naročila kataster kakovosti vode v porečju Pake. Izdelali so ga na podlagi rezultatov monitoringa iz leta 1991 (Rošer Drev in sodelavci 1992). Leta 1991 je bila Paka v zgornjem toku uvrščena v I. kakovostni razred, takoj ko je pritekla na območje Velenja, že v Šaleku, se je poslabšala na II. do III. Nad obrati Gorenja je padla že v III. kakovostni razred, pod izlivom Lepene iz Velenjskega jezera pa v IV. kakovostni razred in takšna tekla do Šmartnega ob Paki, kjer se je zaradi šibke samočistilne sposobnosti izboljšala v III. do IV. kakovostni razred.

\subsection{Sanacijski Program Vode občine Velenje (kasneje Sanacijski program Paka)}

Na osnovi katastra kakovosti Pake so leto kasneje na inštitutu ERICo Velenje izdelali strokovne osnove za sanacijski program Vode občine Velenje (Šterbenk 1993). Temeljil je na široki analizi kemijskih in bioloških parametrov. Tiste čase je bil to najširše usmerjen načrt v Sloveniji. Sanacijski program ni bil namenjen le reševanju problematike komunalnih odpadnih voda, ampak je bil obenem tudi program najpomembnejših uporabnikov in onesnaževalcev vode na tem območju: Termoelektrarne Šoštanj, Tovarne usnja Šoštanj, Gorenja, Premogovnika Velenje ... Sanacijski program, sprejet leta 1994, so sestavljali trije 
podprogrami: Tekoče vode, Jezera in Kanalizacija, katerih skupne cilje smo ob sprejetju sanacijskega programa strnili v tri točke:

- izboljšati kakovost tekočih voda v občini Velenje, ki so v III. in IV. kakovostnem razredu, v najmanj II. kakovostni razred ter sonaravno urediti njihove struge in bregove;

- Družmirsko jezero ohraniti na sedanjem kakovostnem nivoju, ostala jezera pa izboljšati do zmerno evtrofnega stanja in urediti jezerske bregove;

- ves čas sanacije in po opravljeni sanaciji redno izvajati monitoring in vzdrževati doseženo stanje.

Slika 1: I. faza Centralne čistilne naprave je bila zgrajena že leta 1990.

Figure 1: Phase I of the Central WWTP of the Šalek Valley was built already in 1990.

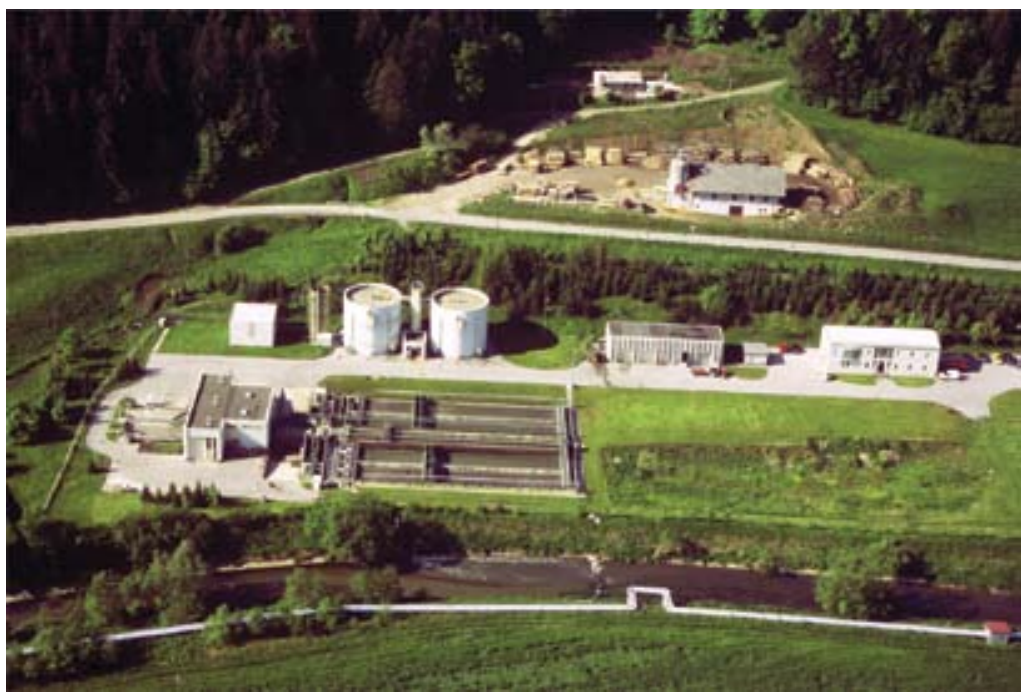

Foto: E. Šterbenk, 1997

Ključne naloge, ki so se prepletale skozi vse tri podprograme so bile posodobitev in dograditev kanalizacijskega sistema (karta), gradnja druge faze centralne čistilne naprave Šaleške doline in zaprtje transportnega sistema za elektrarniški pepel. Obstoječe parcialne kanalizacijske sisteme so na komunalnem podjetju povezali že hitro po izgradnji prve faze čistilne naprave, prav tako so začeli graditi kanalizacije v pojezerju. Prva veja v pojezerju Škalskega jezera je začela delovati že leta 1994, istega leta pa tudi zaprti transportni sistem za transport elektrarniškega pepela. Pepelna transportna voda od takrat kroži med območjem, ki ga zapolnjujejo s pepelom in elektrarno ter praktično ne vstopa $v$ sistem naravnega kroženja vode, po letu 2000 pa večji del pepela transportirajo s kamioni, tako da so obremenitve vode še manjše.

Leta 1995 se je kakovost Pake znatno izboljšala. Poleg v prejšnjem odstavku naštetih ukrepov je usnjarna svoje odpadne vode speljala na centralno čistilno napravo, v Gorenju pa so zmanjšali količino odpadnih voda in povečali učinkovitost njihovega čiščenja. V Paki so 
do njenega izliva v Savinjo po več kot desetletju spet plavale ribe, kakovost vode ni bila nikjer slabša od III. kakovostnega razreda.

Naslednje leto (1996) se je Paka malce poslabšala v zgornjem toku, saj je v Šaleško dolino pritekla v I. do II. razredu, potem pa je do izliva Lepene iz Velenjskega jezera padla v II. do III. razred. Njena kakovost se pod izlivom Lepene ni več poslabšala in je $\mathrm{v}$ istem razredu pritekla do centralne čistilne naprave. Tam se je poslabšala za pol razreda, toda $\mathrm{v}$ spodnjem toku se je zaradi povečane samočistilne sposobnosti ponovno izboljšala v II. do III. kakovostni razred. Izboljšanje Pake za en oziroma en in pol kakovostni razred je bila pomembna sprememba, saj je bila še tri leta pred tem $v$ IV. razredu.

V začetku 21. stoletja se je Paka v Šoštanju znova poslabšala, saj na mehanskem delu čistilne naprave niso mogli dovolj dobro prečistiti vedno večje količine odpadnih vod iz močno razširjenega kanalizacijskega sistema, ki so tja pritekle po kolektorju. Nad Velenjem je Paka večinoma ostala v I. - II. razredu, v Pesju se je občasno poslabšala do III. kakovostnega razreda. V Skornem je v obdobju po letu 2000 prevladoval III.-IV. kakovostni razred, leta 2004 pa so meritve na tem mestu pokazale celo IV. razred kakovosti. Temu je ob vedno večji količini odpadne vode iz razširjenega kanalizacijskega sistema in nedograjeni čistilni napravi botroval nizek poletni pretok. Do Šmartnega ob Paki se je kakovost Pake izboljšala večinoma do III. kakovostnega razreda.

\subsection{Priprave na gradnjo II. faze čistilne naprave}

Župan MO Velenje je leta 1996 imenoval interdisciplinarno skupino strokovnjakov za pripravo dokumentacije za gradnjo II. faze centralne čistilne naprave Šaleške doline (biološkega dela in potrebne posodobitve obstoječe I faze že obratujočega mehanskega dela). Skupina so sestavljali strokovnjaki tehnologije čiščenja ter strojnega, gradbenega in elektro področja s Kemijskega inštituta iz Ljubljane, Termoelektrarne Šoštanj, Gorenja, inštituta ERICo Velenje in Komunalnega podjetja Velenje. Projektna skupina je zbrala in obdelala vse relevantne podatke potrebne za projektiranje in oblikovala natančno projektno nalogo, ki je tvorila vsebinski del razpisa.

Skupina je pripravila tudi dvostopenjski mednarodni razpis za izdelavo idejnega projekta $v$ več variantah. $V$ prvi stopnji razpisa je bilo izmed 12 ponudnikov za nadaljnji postopek izbranih 6 ustreznih. Na drugi stopnji je bil izmed njih izbran domači ponudnik v povezavi z nemškim podjetjem, zadolženim za projektiranje tehnologije. Na ta način smo dosegli kvaliteten prenos tehnološkega znanja iz tujine. Izbrani izvajalec je v letu 1996 in 1997 pripravil idejne zasnove $\mathrm{v}$ treh variantah; klasična, tehnologija biofiltracije in tehnologija $\mathrm{s}$ sekvenčnimi reaktorji. Na stopnji idejnega projekta sta bili obdelani klasična in tehnologija biofiltracije. Tako pridobljena dokumentacija je bila temelj za nadaljevanje priprave gradnje in odločitve v zvezi z dokončno izbiro tehnologije in načinom financiranja.V nadaljevanju je bil pripravljen investicijski program ki je dokončno opredelil vse stroške investicije in finančne vire.

$\mathrm{Na}$ osnovi primerjave variant idejnega projekta in investicijskega programa je skupina izbrala tehnologijo biofiltracije. Poglavitni razlogi za to odločitev so bili: 
- razpoložljivi prostor za gradnjo je komaj zadostoval za umestitev klasične tehnologije z velikimi reaktorji;

- tehnologija biofiltracije zaseda slabih $40 \%$ prostora potrebnega za klasično tehnologijo, ostaja še znaten del prostora za morebitne širitve ali dograditve naprave zaradi možnosti zakonsko povečanih zahtev pri čiščenju $\mathrm{v}$ prihodnosti, ki v danem trenutku niso bile znane;

- neugodne geološke razmere in konfiguracija terena bi zahtevali velike izkope in posebne ukrepe pri temeljenju objektov po klasični tehnologiji;

- manjši objekti so pejsažno sprejemljivejši za okoliško prebivalstvo, arhitektonsko jih je lažje umestiti v pokrajino, ki je že tako zelo gosto poseljena;

- v primeru motečih vplivov na bližnjo okolico, najbližje družinske hiše so oddaljene manj kot 200 metrov, se manjše objekte biofiltracije da zapreti z mnogo manjšimi stroški kot velike, zgrajene po klasični tehnologiji;

- izračuni v dokumentaciji so pokazali, da bo cena investicije za tehnologijo biofiltracije nekoliko nižja kot za klasično, stroški obratovanja pa enaki.

\subsection{Dokončanje centralne čistilne naprave Šaleške doline, zakonske osnove}

Nadgradnja Centralne čistilne naprave Šaleške doline in kanalizacijskih omrežij je eden najpomembnejših korakov za varovanje voda Šaleške doline in s tem tudi za varovanje okolja in ohranjanje narave. Zato ne preseneča, da je bila označena kot osrednji cilj sanacijskega programa.

V času priprave projektno tehnične dokumentacije za rekonstrukcijo I. faze in nadgradnjo centralne čistilne naprave Šaleške doline (II. faza) je že bila uveljavljena nova okoljska zakonodaja, ki je temeljila na načelih trajnostnega razvoja ter smernicah in direktivah Evropske Unije. Sprejet je bil nov Zakon o varstvu okolja (ZVO-1, Ur. list RS št. 41/04), ki določa, da je potrebno za delovanje naprave, ki povzroča emisije v zrak, vode ali tla, za katere so predpisane mejne vrednosti skladno z določbami tega zakona, pridobiti okoljevarstveno dovoljenje. Ta zakon tudi določa, da je za tiste posege v prostor, za katere je obvezna presoja vplivov na okolje, potrebno pridobiti okoljevarstveno soglasje. To obveznost pa določa Uredba o vrstah posegov v okolje, za katere je obvezna presoja vplivov na okolje (Ur. list RS št. 66/96, 12/00, 83/02). ZVO-1 nadalje določa, da se v postopku presoje vplivov na okolje ugotovi, opiše in oceni dolgoročne, kratkoročne, posredne in neposredne vplive nameravanega posega na človeka, tla, vodo, zrak, biotsko raznovrstnost in naravne vrednote, podnebje in krajino, pa tudi na človekovo nepremično premoženje in kulturno dediščino ter njihova medsebojna razmerja.

Za dograditev centralne čistilne naprave Šaleške doline (II. faza) je bilo potrebno pridobiti okoljevarstveno dovoljenje, obvezna pa je bila tudi presoja o vplivih na okolje, iz česar je sledilo, da je potrebno pridobiti tudi okoljevarstveno soglasje. V skladu z določbami ZVO-1 je bilo možno oba postopka združiti v enega tako, da so bile pri določanju vsebine okoljevarstvenega dovoljenja upoštevane tudi določbe, ki se nanašajo na vsebino okoljevarstvenega soglasja. V okviru presoje vplivov na okolje je bil preučen tudi vpliv na 
Slika 2: Kanalizacijsko omrežje v Šaleški dolini

Figure 2: Sewage system of the Šalek Vally

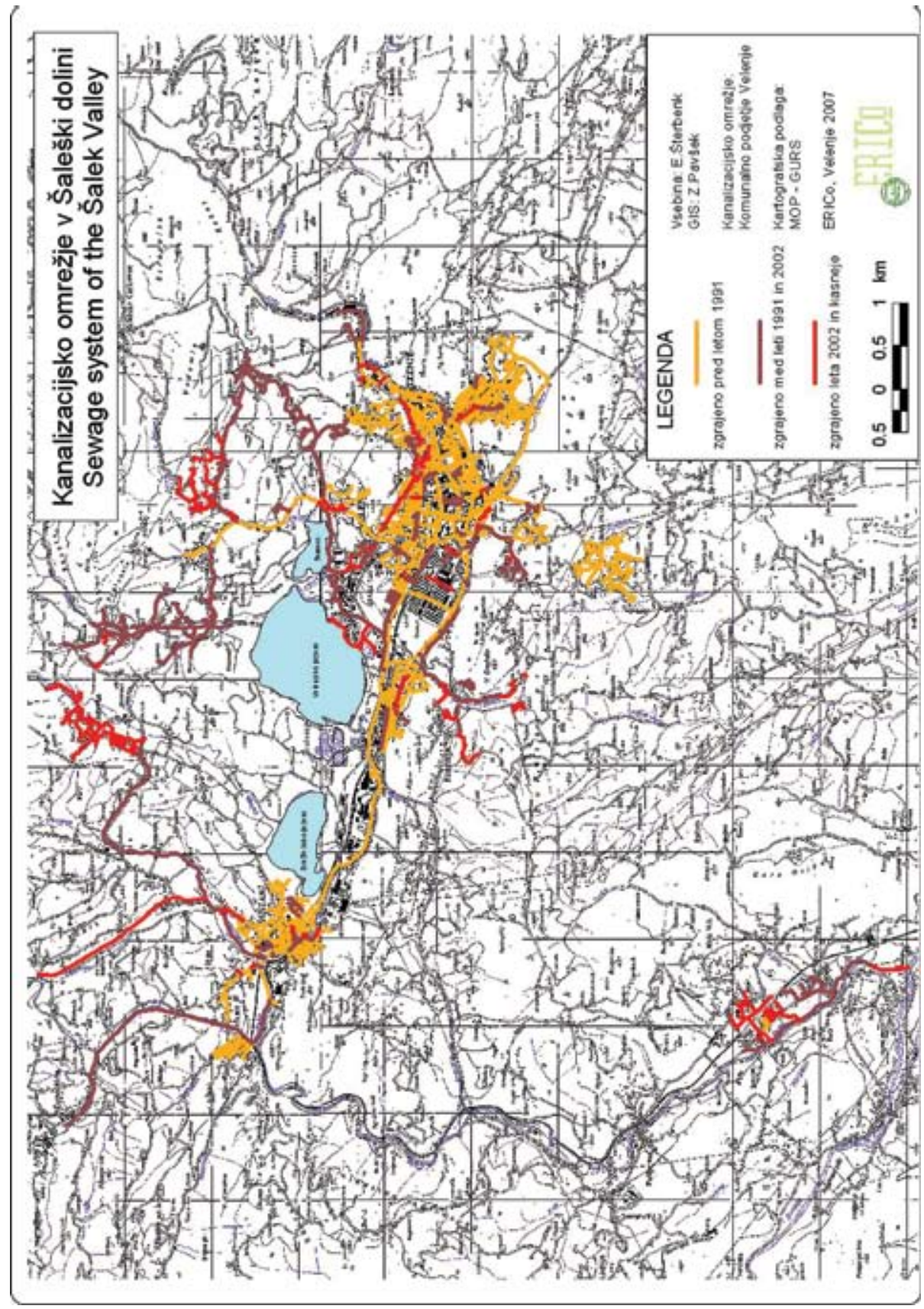


vode. Podrobnejša določila v zvezi s kakovostjo vode so določena v Uredbi o emisiji snovi in toplote pri odvajanju odpadnih voda iz virov onesnaženja (Ur. list RS št. 35/96, 21/03) ter Uredbi o emisiji snovi pri odvajanju odpadnih vod iz komunalnih čistilnih naprav (Ur. list RS št. 35/96, 90/98, 31/2001). V okviru rekonstrukcije in dograditve centralne čistilne naprave Šaleške doline (II. faza) je bila predvidena nadgradnja z biološkim čiščenjem odpadnih vod, ki omogoča tudi odstranjevanje dušikovih in fosforjevih spojin iz odpadne vode. Mejne vrednosti snovi v odpadni vodi na iztoku iz čistilne naprave v Pako so predvidene v skladu z dopustnimi vrednostmi iz navedenih uredb, razen za KPK, celotni dušik in celotni fosfor. Zaradi znatnega vpliva odpadnih vod na reko v času nizkih vodostajev so se za mejne vrednosti celotnega dušika in celotnega fosforja upoštevale dopustne mejne vrednosti, ki so predpisane za iztoke odpadnih voda na občutljivih območjih, čeprav Paka ni na seznamu teh območij. Mejna vrednost KPK pa je nižja od predpisane po uredbi na posebno zahtevo investitorja.

Na podlagi teh izhodišč ter zaključkov poročila in ocene vplivov na okolje II. faze centralne čistilne naprave Šaleške doline je Agencija RS za okolje izdala okoljevarstveno dovoljenje za obratovanje centralne čistilne naprave glede emisije v vode za določen čas in sicer za dobo 5 let.

V letu 2002 je bil uveljavljen tudi nov Zakon o vodah (Ur. list RS št. 67/02), ki določa, da je potrebno za vse posege, ki lahko vplivajo na vodni režim in stanje voda pridobiti vodno soglasje. Na podlagi tega zakona je Agencija RS za okolje izdala informacijo o pogojih gradnje ter vodno soglasje, v katerem je poleg pogojev za kakovost presojala tudi vplive na vodni režim in poplavno varnost območja.

\subsection{Financiranje gradnje II. Faze čistilne naprave}

Občini Velenje in Šoštanj sta pripravo in izgradnjo II. faze centralne čistilne naprave Šaleške doline v celoti zaupali Komunalnemu podjetju Velenje. Glavna ovira izgradnje je bila v pomanjkanje finančnih sredstev. Že leta 1996 so imenovali posebno projektno strokovno ekipo za vodenje vseh postopkov načrtovanja in gradnje naprave. V letu 1997 so bili izdelani idejni projekti z variantnimi rešitvami. Leto kasneje (1998) je Komunalno podjetje Velenje izdelalo »Dolgoročni program naložb v vodooskrbni sistem ter naložb v odvajanje in čiščenje odpadnih in padavinskih voda«, ki ga je Ministrstvo za okolje in prostor RS leta 1999 uvrstilo v »Nacionalni program RS za varstvo okolja«. To sta bila temelj in možnost za zaključevanja finančne konstrukcije tudi s sredstvi EU, ki so se pojavila v tem obdobju.

EU je že v zelo zgodnji fazi svojega razvoja prišla do spoznanja, da velike ekonomske in socialne razlike $v$ razvitosti med posameznimi regijami in državami ovirajo trajnostni razvoj skupnosti kot celote. Da bi k reševanju teh problemov pristopila kar najbolj celovito, je zato že pred desetletji začela z izvajanjem tako imenovane kohezijske politike, ki temelji na načelu solidarnosti, saj je usmerjena v pospeševanje razvoja tistih regij in držav, ki so gospodarsko in socialno v slabšem položaju od povprečja EU. Temeljni cilj kohezijske politike je torej prispevati k zmanjševanju razlik v razvitosti med posameznimi deli in regijami EU.

Lastna sredstva za gradnjo tako velike in zahtevne naložbe kot je CČN ne bi zadoščala. Izgradnja II. faze CČN Šaleške doline je namreč brez stroškov dokumentacije znašala 10,125 
milijonov $€$ oziroma $202,4 €$ na PE. Pokazala se je možnost, da bi gradnjo tega prepomembnega objekta lahko v veliki meri financirali iz nepovratnih sredstev Evropskega predstrukturnega sklada ISPA. Leta 2001 je bil projekt uspešno prijavljen na komisijo EU, prav tako je bilo sklenjeno uspešno sodelovanje z Ministrstvom za okolje in prostor RS, ki je iz državnega proračuna zagotovilo dodatna sredstva za sofinanciranje projekta. Za pokrivanje razlike med lastnimi in nepovratnimi sredstvi so bili najeti ugodni krediti, predvsem ugoden je bil kredit Ekološkega sklada RS. Finančni memorandum o sofinanciranju gradnje CČN ŠD med Evropsko komisijo in RS so podpisali 18. junija 2002. Obe podpisnici sta vse pristojnosti vodenja projekta in gradnje poverili lokalni skupnosti ta pa Komunalnemu podjetju Velenje.

$\mathrm{Z}$ zaprtjem finančne konstrukcije, izdelano projektno in investicijsko dokumentacijo ter zaključenim upravnim postopkom so bili izpolnjeni vsi pogoji za gradnjo naprave. Konec aprila 2004 je bil objavljen mednarodni razpis. Izbran je bil izvajalec, ki je z delom začel konec decembra 2004. Rok za zaključek projekta, ki je pred izgradnjo naprave vključeval tudi izdelavo tehnične in izvedbene dokumentacije ter pridobitev gradbenega dovoljenja je bil 600 dni. Napravo so zgradili septembra 2006, takrat se je začelo poskusno obratovanje, ki se je končalo novembra 2007.

Preglednica 1: Finančna konstrukcija za izgradnjo II. faze centralne čistilne naprave Šaleške doline

Table 1: The budged scheme for building of the phase II of the WWTP of the Šalek Valley

\begin{tabular}{|l|c|c|}
\hline Vir financiranja & V evrih & $\%$ \\
\hline Lastna sredstva za razširjeno reprodukcijo & 208.000 & 2,1 \\
\hline Okoljska dajatev za obremenjevanje voda & 1.334 .000 & 13,2 \\
\hline Sofinanciranje MOP RS & 2.533 .000 & 25,0 \\
\hline Kredit Ekološkega sklada & 1.958 .333 & 19,3 \\
\hline EU ISPA kohezijski sklad & 3.875 .000 & 38,3 \\
\hline Ostalo krediti & 216.667 & 2,1 \\
\hline SKUPAJ & 10.125 .000 & 100,0 \\
\hline
\end{tabular}

Ob gradnji te faze je bil poglavitni cilj zagotoviti potrebna finančna sredstva za sodobno in učinkovito napravo. Zadana naloga je bila uspešno realizirana, saj naprava kaže zelo dobre učinke čiščenja, samo gradnja pa se je financirala iz dveh tretjin tujih nepovratnih virov. Postavljen finančni model se je pokazal kot izjemno učinkovit. Vložek nepovratnih sredstev iz EU so nadgradili še s finančnimi viri iz proračuna RS, sredstvi okoljskih dajatev in ugodnimi ekološkimi krediti ter lastnimi sredstvi.

Izbrani način financiranja se je izkazal kot zelo učinkovit. Če v Šaleški dolini doslej ne bi nič investirali v čiščenje komunalnih odpadnih voda, bi vsak uporabnik moral letno plačevati 38 evrov okoljske dajatve za obremenjevanje voda in II. fazo CČN Šaleške doline bi z izključno temi sredstvi lahko zgradili v osmih letih. Tako pa smo od leta 1999 do 2005 zgradili večino kanalizacije okoli Šaleških jezer in manjši del v drugih naseljih mestne občine Velenje ter občine Šoštanj in čistilno napravo z delom kanalizacije v občini Šmartno ob Paki. 
Ker je mehanska stopnja CČN Šaleške doline ob začetku te investicije že obratovala, so uporabniki plačevali vsega 25 evrov letne okoljske dajatve, zato bi gradnjo naprave s temi sredstvi financirali skoraj 12 let. Večja ekonomska učinkovitost se je pokazala tudi z izračunom ekonomskih kazalnikov uporabljenega modela, kjer je količnik med koristmi in stroški bistveno večji, če se je naprava gradila krajše obdobje.

\subsection{Osnovni opis čistilne naprave}

Prvo fazo čistilne naprave so zgradili leta 1990 in takrat je začela tudi poskusno obratovati. Zgradili so mehanski del čistilne naprave (grablje, sito, ozračeni peskolov in maščobnik ter primarne usedalnike). Postavili so tudi linijo stabilizacije blata in kljub omejenim možnostim biološko delno čistili odpadne vode. Po 16 letih obratovanja je oprema dotrajala ali tehnološko zastarela, zato so ob rekonstrukciji mehanski del naprave temeljito obnovili. Obstoječi napravi so dodali drugo in tretjo stopnjo čiščenja. Naprava je dimenzionirana za čiščenje komunalne odpadne vode in onesnažene padavinske vode (50.000 PE), ki se zbira v mešanem kanalizacijskem sistemu Šaleške doline.

Centralno čistilno napravo po rekonstrukciji starega in izgradnji biološkega dela sestavljajo naslednji moduli: mehansko čiščenje komunalne odpadne vode, biološko čiščenje (biofiltracija), predelava blata in koriščenje gniliščnega plina za pridobivanje električne energije ter sistem vodenja s stalnim monitoringom ki je osnova za avtomatsko regulacijo procesov.

V okviru centralne čistilne naprave Šaleške doline je zgrajen kemijski in mikrobiološki laboratorij za kontrolo pitne in tople sanitarne vode ter kontrolo postopkov čiščenja odpadnih voda. To daje vodooskrbi in čiščenju novo kakovost in možnost preventivnega ukrepanja na vodooskrbnih sistemih ter omogoča suvereno obvladovanje procesov čiščenja.

\subsection{Delovanje čistilne naprave s pritrjeno biološko rušo}

Voda priteče iz kolektorja v linijo mehanskega čiščenja skozi grobe grablje, kjer odstranijo največje delce. $V$ črpališču jo dvignejo na takšno višino, da do linije biološkega čiščenja teče skozi napravo gravitacijsko (Slika 3). Nato voda teče skozi fine grablje, kjer odstranijo delce do velikosti $6 \mathrm{~mm}$, od tam v vzporedna ozračena peskolova, ki sta obenem maščobnika ter na koncu v primarna usedalnika, do črpališča na biološko stopnjo čiščenja vode, Pred črpališčem so naslednje fine grablje. Te preprečijo vstop delcev do velikosti 2 mm. Odpadno vodo mehansko očistijo; v celoti odstranijo večje mehanske delce, pesek in maščobe. V primarne usedalnike priteka še pralna voda (odvečno blato) iz bioloških filtrov. Sestavni del linije mehanskega čiščenja vode je sprejemno mesto za greznične vsebine in črpališče za črpanje usedlega blata v linijo stabilizacije blata. Mehansko očiščena voda je pripravljena za nadaljnje čiščenje v biofiltrih.

Iz primarnih usedalnikov črpajo vodo v linijo biološkega čiščenja vode. Tudi v tem delu dvignejo vodo tako visoko, da teče gravitacijsko do izliva v Pako. Iz vode najprej odstranijo fosfor. Voda potem teče v biološke filtre za denitrifikacijo (8 enot), od tam pa v biološke filtre 
za nitrifikacijo (8 enot). Voda med filtri za denitrifikacijo in nitrifikacijo delno kroži (povratni vod). Prečiščena voda teče iz tega kroga v bazen za čisto vodo in skozi merilno mesto v Pako. Biološka ruša (aktivno blato) je pritrjena na nosilce (zrna iz ekspandirane gline). Kakovost vode spremljajo skozi ves proces, ki je na podlagi teh podatkov tudi avtomatiziran. V filtre za niktrifikacijo dovajajo zrak, potreben za oksidacijo ogljikovih spojin in dvostopenjsko oksidacijo amonijaka ( $\mathrm{v}$ nitrite in nitrate). $\mathrm{V}$ filtrih za denitrifikacijo $\mathrm{v}$ anaerobnih pogojih razgrajujejo nitrate in $\mathrm{s}$ tem sproščajo dušik $\mathrm{v}$ atmosfero.

Odvišno blato sperejo z nosilcev z močnimi vodnimi črpalkami in z zrakom. Vodo $\mathrm{z}$ blatom prelijejo $\mathrm{v}$ primarne usedalnike, kjer se useda tudi blato $\mathrm{z}$ mehanske stopnje čiščenja. S črpališčem za odvišno blato se začne linija stabilizacije blata. Blato prečrpajo v zgoščevalec. Od tam gre v primarno in sekundarno ogrevano gnilišče, kjer gnije in se s tem stabilizira. Produkt tega procesa je gniliščni plin (metan, ogljikov dioksid ...). Mešanico plinov zbirajo v plinohramu. Plin služi v kotlovnici kot gorivo za ogrevanje gnilišč in/ali za pogon plinskih motorjev, ki vrtijo električne generatorje in pretvarjajo notranjo energijo bioplina v elektriko. Na ta način na čistilni napravi krijejo $30 \%$ potreb po električni energiji, ogrevajo gnilišča in prostore. Biološko blato po zaključeni stabilizaciji črpajo v zalogovnik, potem pa ga dehidrirajo $\mathrm{v}$ centrifugi in ga odpeljejo na odlagališče komunalnih odpadkov. Onesnaženo vodo iz centrifuge vračajo $\mathrm{v}$ proces čiščenja.

\section{Slika 3: Tehnološka shema centralne čistilne naprave Šaleške doline}

Figure 3: Technological scheme of the wastewater treatment plant of the Šalek Valley

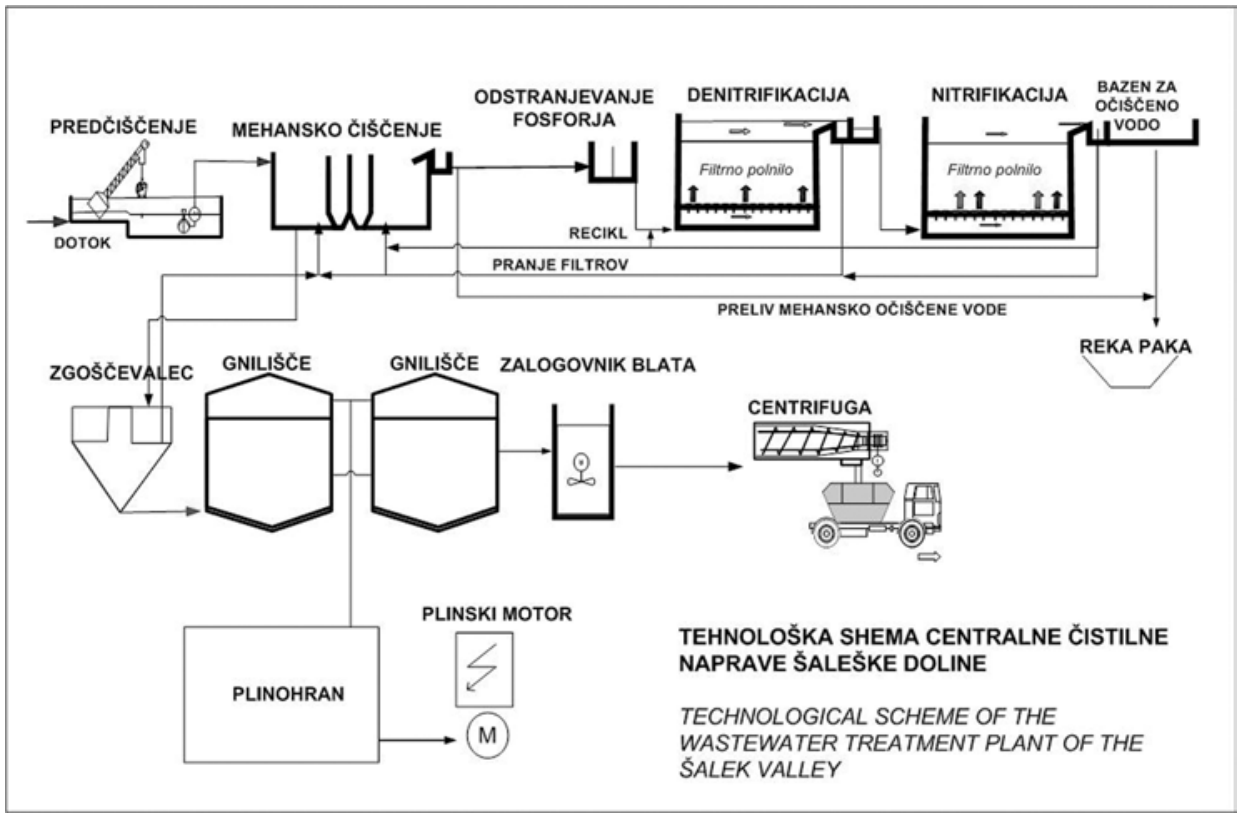


Sistem vodenja se začne s sondami, ki spremljajo različne parametre skozi vse faze čiščenja. Podatki se zbirajo v računalniškem sistemu, ki na njihovi podlagi avtomatično usmerja delovanje naprave. Čistilna naprava lahko obratuje avtomatsko, po potrebi pa jo lahko tudi ročno vodijo. $\mathrm{V}$ prihodnosti predvidevajo popolnoma avtomatsko obratovanje brez redne posadke samo $\mathrm{z}$ daljinskim nadzorom in avtomatskim sporočanjem napak.

\section{ZMANJŠAN NEGATIVNI VPLIV NA PAKO}

Z izgradnjo 2. faze CČN Šaleške doline se je obremenjevanje Pake z različnimi onesnaževali bistveno zmanjšalo. Učinek čiščenja na podlagi Poročila o prvih meritvah (Rošer Drev 2007) po KPK, $\mathrm{BPK}_{5}$, neraztopljenih snoveh, in amoniju presega 90 \% (od 91,9 do 98 \%), Učinek čiščenja po celotnem dušiku pa znaša, 64,6 \%, kar je za tri do petkrat bolje, kot pred začetkom poskusnega obratovanja. Že prve meritve potrjujejo doseganje projektiranih parametrov, povsem natančno sliko delovanja naprave pa bomo dobili, ko bomo lahko s prejšnjimi primerjali celoletne podatke čiščenja odpadne vode v letu 2007.

Slika 4: II. faza Centralne čistilne naprave Šaleške doline je novembra 2007 uspešno zaključila poskusno obratovanje.

Figure 4: The trial operation of phase II of the Central WWTP of the Šalek Valley was successfully completed in November 2007.

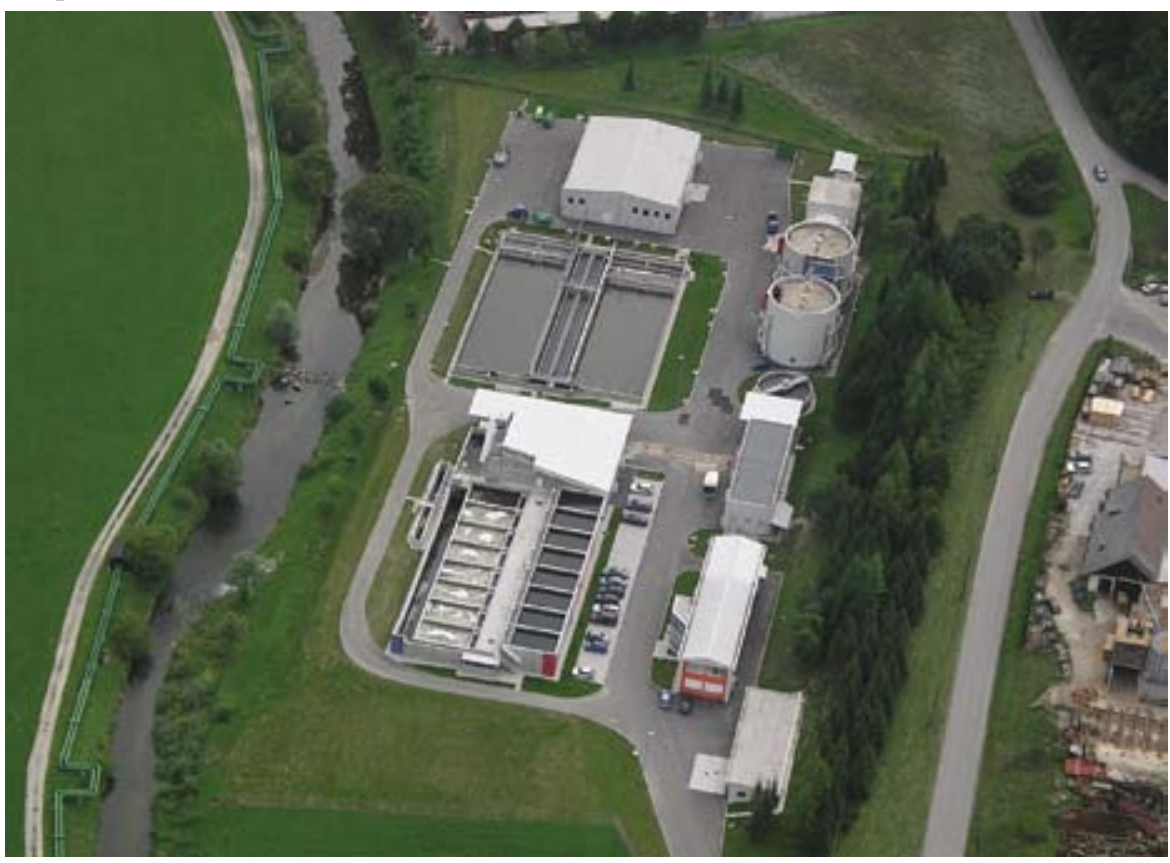

Foto: B. Naveršnik, 2007 
Preglednica 2: Učinek čiščenja na centralni čistilni napravi Šaleške doline /v \%/ (Vir: Rošer Drev 1998, 2003, 2007)

Table 2: Efficiency of wastewater treatment on the Central WWTP of the Šalek Waley /in \%/ (Source: Rošer Drev 1998, 2003, 2007)

\begin{tabular}{|l|c|c|c|}
\hline Parameter/leto & 1997 & 2002 & $2007^{*}$ \\
\hline KPK & 44,6 & 45,5 & 91,9 \\
\hline BPK $_{5}$ & 44,5 & 50,4 & 95,6 \\
\hline Neraztopljene snovi & 57,6 & 48,4 & 97,7 \\
\hline Amonij & 8,8 & 24,0 & 98 \\
\hline Celotni dušik & 21,6 & 9,6 & 64,6 \\
\hline Povprečni pretok (1/s) & 185 & 181 & 129 \\
\hline
\end{tabular}

*Za leti 1997 in 2002 so navedeni celoletni povprečni podatki, za leto 2007 pa podatki po začetku poskusnega obratovanja CČN (meritve od 11. aprila 2007 do 20. junija 2007)

Preglednica 3: Koncentracije onesnaževal v iztoku iz centralne čistilne naprave Šaleške doline (Vir: Rošer Drev 1998, 2003, 2007)

Table 3: Concentrations of pollutants in the outflow of the Central WWTP of the Šalek Valley (Source: Rošer Drev 1998, 2003, 2007)

\begin{tabular}{|l|c|c|c|c|c|c|c|}
\hline \multirow{2}{*}{ Parameter / leto } & \multicolumn{2}{|c|}{1997} & \multicolumn{2}{c|}{2002} & \multicolumn{3}{c|}{$2007^{*}$} \\
\cline { 2 - 8 } & najmanjša & največja & najmanjša & največja & najmanjša & največja & $\begin{array}{c}\text { mejna } \\
\text { vred. }\end{array}$ \\
\hline $\mathrm{KPK}_{(\mathrm{mg} \mathrm{O} / \mathrm{l})}$ & 103 & 194 & 70 & 114 & 30 & 38 & 110 \\
\hline $\mathrm{BPK}_{5}\left(\mathrm{mg} \mathrm{O}_{2} / \mathrm{l}\right)$ & 45 & 90 & 25 & 82 & 9 & 12 & 20 \\
\hline Neraztopljene snovi (mg/l) & 27 & 101 & 41 & 93 & 4 & 11 & 35 \\
\hline Amonij (mg/l) & 7,8 & 23,8 & 0,3 & 22,1 & 0,3 & 0,7 & 10 \\
\hline Celotni dušik (mg/l) & 19,4 & 34,4 & 8,8 & 32,0 & 11,7 & 14,9 & 25 \\
\hline
\end{tabular}

* Mejne (zakonsko dovoljene) vrednosti so navedene za leto 2007(Uredba o emisiji snovi ... Ur. l. RS 45707)

Izgradnja CČN za Šaleško dolino pa ob neposrednem izboljšanju Pake prinaša še druge koristi: izboljšanje Pake pod CČN zaradi izboljšanega učinka čiščenja, možnost uporabe prečiščene vode za tehnološke namene, izboljšanje kakovosti jezer in videza pokrajine, možnosti za razvoj rekreacije in ribolova ter naložb v turistično in rekreacijsko infrastrukturo, izboljšanje kakovosti Savinje in drugo.

\section{USMERITVE ZA PRIHODNOST}

Po zaključeni izgradnji in poskusnem obratovanju druge faze centralne čistilne naprave Šaleške doline ostaja še vrsta nalog na področju varstva voda, ki jih je potrebno izpolniti. Občine v srednjem in spodnjem porečju so že pripravile in sprejele lokalne operativne 
programe odvajanja in čiščenja komunalnih odpadnih voda, ki so osnova za gospodarjenje z odpadnimi vodami.

Lokalni operativni programi predvidevajo sanacijo neustreznih in netesnih delov kanalizacijskega omrežja (odseki starosti med 30 in 40 let) in novogradnje. Na kolektorju odpadnih voda je potrebno zgraditi zadrževalne bazene in razbremenilnike. Ob večjih padavinah v zadrževalnih bazenih zajamejo prvi val najbolj onesnažene padavinske vode (prve padavine izperejo nesnago iz utrjenih prometnih in drugih površin), kasnejše bolj čiste spustijo mimo kanalizacije neposredno v vodotok. Na ta način ne motijo obratovanja čistilnih naprav zaradi prevelikih pretokov, v naravi pa ne povzročijo škode. V posameznih naseljih so še vedno objekti, ki niso priključeni na kanalizacijske sisteme, zato ostaja njihovo priključevanje pomemben cilj.

Na območjih zgornjih tokov Pake in njenih pritokov kanalizacije praktično ni. Na redkeje poseljenih območjih bo potrebno individualno reševanje odvajanja in čiščenja odpadnih voda, v zaselkih pa bodo gradili skupinske in lokalne čistilne naprave. Tu načrtujejo tudi ekoremediacije, ne zgolj gradnjo konvencionalnih manjših čistilnih naprav. Zaradi majhne vodnatosti v povirjih je osnovna usmeritev: prečiščeno vodo čim hitreje vrniti v vodotoke. Pomemben vir sredstev za večje načrtovane investicije bodo kohezijski skladi EU. Regionalna politika v EU temelji na finančni solidarnosti med državami, katere osnovni cilj je zmanjševanje gospodarskih in socialnih neenakosti med različnimi regijami v Skupnosti. Ta politika omogoča prenos sredstev dela proračuna EU pretežno bogatih držav članic v najmanj razvite regije. Tak pristop ne pomaga le državam prejemnicam, ampak tudi tistim, ki so neto plačnice v proračunu, saj njihova podjetja $\mathrm{v}$ zameno pridobijo večje investicijske možnosti, še posebej v regijah, kjer se nekatere vrste gospodarskih dejavnosti še niso razvile, poleg tega pa se poveča tudi prenos tehnologij in znanja. Regionalna politika tako omogoča vsem regijam, da pripomorejo večji skupni konkurenčnosti EU in prispevajo dolgoročnemu razvoju. Kohezijski sklad skrbi za financiranje projektov, namenjenih izboljšanju okolja ter razvoju prometne infrastrukture $\mathrm{v}$ državah članicah, katerih bruto nacionalni proizvod (BNP) na prebivalca je manjši od 90 odstotkov povprečja EU.

Pogoji oziroma kriteriji za financiranje iz sredstev kohezijskega sklada so: okoljski vidik projekta, uvrščenost v nacionalni program države prijaviteljice, podpora lokalnih skupnosti, celovitost projekta, vrednost projekta nad 10 mio evrov, financiranje samo magistralnih in primarnih omrežij, vrednost pod 800 evrov na PE pri investiciji, $\breve{C N}$ za odpadne vode nad 2000 PE, ekonomska upravičenost projekta (razmerje med donosi in stroški, NSV, ISD in vrsto drugih kazalcev), vsa potrebna investicijska, tehnična, upravna in ostala dokumentacija ter drugi pogoji.

Ob kandidaturi za sredstva kohezijskih skladov je potrebno priložiti vrsto dokumentov: predinvesticijske študije, idejne študije in idejne zasnove ter lokalne operativne programe, dokumente identifikacije investicijskih projektov, predinvesticijske zasnove, študije izvedljivosti projekta, študije stroškov in koristi, vloge za pridobitev sofinanciranja iz kohezijskih skladov, izvedbeno dokumentacijo, investicijski program, izvedbo javnih razpisov za oddajo del (v kolikor pride do sofinanciranja EU). 


\section{SKLEP}

Paka se je od začetka osemdesetih let dvajsetega stoletja iz popolnoma onesnaženega spremenila v zmerno obremenjen vodotok. Uspeh ni prišel sam po sebi, saj sta bili za spremembo potrebni kar dve desetletji usmerjenega dela. Izjemna onesnaženost Pakev spodnji tretjini njenega toka, onesnaženost nekaterih pritokov ter Škalskega in Velenjskega jezera je zahtevala celovito sanacijo. Občina Velenje je zasnovala sistem sanacijskih programov, med katerimi je bil tudi program za vode. Temeljil je na realnih in podrobnih podatkih monitoringa in k ciljem izboljšanja vode združil občinske strukture, komunalno podjetje, uporabnike in onesnaževalce vode ter celotno javnost. Prve korenite izboljšave so se začele leta 1994 s sprejetjem programa na takratni občinski skupščini, z izboljšavami v energetiki in industriji ter s širjenjem in povezovanjem kanalizacijskih sistemov. Izgradnja centralne čistilne naprave Šaleške doline je bila ob zmanjšanju negativnih vplivov iz energetike in industrije ključna naloga Sanacijskega programa Paka in temeljni pogoj, da se zastavljeni cilji dosežejo. Zaradi majhne vodnatosti Pake, intenzivnih antropogenih dejavnosti v njenem porečju in nihanju količine odpadnih voda so izbrali napredno tehnologijo pritrjene biološke ruše - biofiltracijo. Seveda je bilo pred gradnjo potrebno zagotoviti vso potrebno infrastrukturo, od kanalizacijskih vodov in črpališč, do nadzornih sistemov.

Dobra lastnost trajnostno naravnanega sanacijskega programa je, da se prilagaja trenutni situaciji in da se doseženi uspehi sproti evidentirajo in vrednotijo. Sanacijski program je od njegovega sprejetja leta 1994 rasel in se postopoma spremenil v program gospodarjenja z vodami v porečju Pake. Program je razširjen tako teritorialno kot vsebinsko. Po letu 2003 namreč v okviru tega programa ob odpadnih obravnavamo še pitne vode. Dobri rezultati potrjujejo ustreznost pristopa in kar kličejo po implementaciji teh principov v drugih porečjih v Sloveniji in drugod, zlasti v okoljsko manj ozaveščenih in slabše urejenih državah Jugovzhodne Evrope.

\section{Viri in literatura}

Dular, M, Zagorc-Končan, J, Rejic, M, Jedovnicki, M, 1984. Reševanje problematike odpadnih vod iz energetskih obratov. Varstvo okolja pri energetskih objektih, zbornik referatov. Termoelektrarna Šoštanj. Šoštanj.

Lokalni operativni program odvajanja in čiščenja komunalnih odpadnih voda za območje občine Šmartno ob Paki, 2005. Komunalno podjetje Velenje. Velenje.

Lokalni operativni program odvajanja in čiščenja komunalnih odpadnih voda za območje občine Šoštanj, 2005. Komunalno podjetje Velenje. Velenje.

Lokalni operativni program odvajanja in čiščenja komunalnih odpadnih voda za območje Mestne občine Velenje, 2005. Komunalno podjetje Velenje. Velenje.

Ramšak, R., 2007. Raziskave in spremljanje kakovosti jezer v Šaleški dolini. Poročilo za leto 2005, ERICo Velenje. Velenje.

Rošer Drev, A., 1987. Vpliv odpadnih voda na kakovost reke Pake - hidrobiološka analiza. Diplomska naloga. Biotehniška fakulteta. Ljubljana. 
Rošer Drev, A., 1998. Poročilo o obratovalnem monitoringu Centralne čistilne naprave za leto 1997. ERICo Velenje, ERICo.

Rošer Drev, A., 2003. Poročilo o obratovalnem monitoringu Centralne čistilne naprave za leto 2002. ERICo Velenje, ERICo.

Rošer Drev, A., 2007. Poročilo o prvih meritvah na Centralni čistilni napravi Šaleške doline. ERICo Velenje, ERICo.

Rošer Drev, A., Ramšak, R., Bole, M, Kugonič, N, 1992. Kataster voda občine Velenje. ERICo Velenje. Velenje.

Šterbenk, E., 1993. Vode občine Velenje, sanacijski program (strokovne osnove). ERICo Velenje. Velenje.

Šterbenk, E., Rošer Drev, A., 1997. Poročilo o cvetenju Velenjskega jezera avgusta 1997. ERICo Velenje. Velenje.

Šterbenk, E., 1999. Šaleška jezera, Vpliv premogovništva na pokrajinsko preobrazbo Šaleške doline. Pozoj Velenje, ERICo Velenje. Velenje.

Šterbenk, E., Kregar, L., Pavšek, Z., 2000. Gospodarjenje z vodami v pridobivalnem prostoru Premogovnika Velenje. Zaključno poročilo - sintezni del, PUV Celje in ERICo Velenje. Velenje.

Šterbenk, E., 2003. Vloga vodnih virov v trajnostno sonaravnem razvoju Šaleške doline in obrobja. Letno poročilo 2002, ERICo Velenje. Velenje.

Jamomerstvo Premogovnika Velenje, 2007. Baza podatkov.

\section{REALIZING OF PRINCIPLES OF SUSTAINABLE DEVELOPMENT IN SMALL OVERBURDENED WATERSHEDS}

\section{Central wastewater treatment plant of the Šalek Valley, main measure of the Water improvement programme Paka}

\section{Summary}

The Šalek Valley is overburdened with many human activities The river Paka is too small for an industrially and energetically intensive area. Not only environmental pollution itself, but also changes in the river network have enlarged the sensitivity of the water bodies. Due to coalmining the surface of the Šalek Valley has subsided and subsidence lakes have appeared. A high standard of measures for environmental protection is necessary to prevent the pollution of these lakes. Due to the poor quality of the river Paka at the beginning of nineties, a Water improvement programme was adopted.

The main goal of the programme was to improve the Paka to the $2^{\text {nd }}$ quality class. A lot of environmental improvement activities have been carried out. Main measure for improving of the river Paka was upgrading the wastewater treatment plant (WWTP). A financial grant of almost $40 \%$ was awarded by the European Union's ISPA financial instrument for carrying out the project. Not only the WWTP, also the sewage system had to be re-built and modernised. The phase I of the WWTP was built already in 1990, but it was not efficient enough to prevent pollution of the river Paka. In 1996 an interdisciplinary group of experts was set up to propose 
the most suitable technology for treatment of wastewater. A method of bio-filtration (fest bed method) for treatment of wastewater has been chosen. The construction of the WWTP began in 2005 and a year later trial operation of the plant was started. The WWTP has been in function since that time and the quality of outflow of treated water increased significantly. Additionally, improvement of the river Paka was indicated by results of monitoring. The trial operation was successfully finished at the end of 2007 and the plant has been put in regular operation. By this measure also the main goal of the Water improvement programme $\left(2^{\text {nd }}\right.$ quality class of the river Paka) has become much more achievable.

Although the river Paka is one of the most burdened water bodies in Slovenia, the results of the water improvement programme have shown that it is possible to direct development towards sustainability even in highly populated areas. We cannot say yet that sustainable development is achieved but it is possible to say that recent development is more sustainable. The results are quite good, but we must not forget that the first activities (monitoring of water bodies) started back in 1987. The improved state of the water bodies and a high standard of wastewater treatment are results of monitoring, a systematically prepared improvement programme and coordinated and well-performed water protection measures. Methodology of environmental improvement of Paka watershed has shown for very successful and it could be adjusted and applied also in other similar high overburdened areas. 